\title{
Effects of inorganic nutrients and organic matter on microbial euendolithic community composition and microbioerosion rates
}

\author{
M. Carreiro-Silva ${ }^{1,4, *}$, T. R. McClanahan ${ }^{2}$, W. E. Kiene ${ }^{3}$ \\ ${ }^{1}$ Chesapeake Biological Laboratory, University of Maryland, Center for Environmental Science, Solomons, \\ Maryland 20688-0038, USA \\ ${ }^{2}$ Marine Programs, Wildlife Conservation Society, 2300 Southern Blvd, Bronx, New York 10460-1099, USA \\ ${ }^{3}$ NOAA/Office of National Marine Sanctuaries, Southeast, Gulf of Mexico and Caribbean Region, 4700 Ave U, Galveston, \\ Texas 77551, USA \\ ${ }^{4}$ Present address: Departamento de Oceanografia e Pescas, Universidade dos Açores, 9901-862 Horta, Portugal
}

\begin{abstract}
Closed cages were used in Glovers Atoll, Belize to test the effects of organic matter (OM) and inorganic nutrient $(\mathrm{N}+\mathrm{P})$ additions on microbial euendolithic communities (bacteria, fungi, and algae) and their rates of bioerosion of Strombus gigas shells during a $49 \mathrm{~d}$ fertilization experiment. We hypothesized that the addition of OM would release heterotrophic microborers from C-limitation and at the same time reduce light levels for euendolithic microalgae, thus changing the microborers' community composition and their bioerosion rates. The addition of OM increased the abundance of heterotrophs (particularly fungi), but only when OM was added alone, not when it was combined with inorganic nutrients. In contrast, both cyanobacteria and green algae were stimulated by the addition of inorganic nutrients, but were not affected by $\mathrm{OM}_{\text {; }}$ these taxa were 4 times more abundant in treatments with inorganic nutrients than in control and OM treatments. Green algae dominated the control, $\mathrm{N}+\mathrm{P}$ and $\mathrm{N}+\mathrm{P}+\mathrm{OM}$ treatments ( 77 to $87 \%$ green algae, 6 to $8 \%$ cyanobacteria, 4 to $16 \%$ heterotrophs), whereas in the OM treatment, heterotrophs represented nearly $50 \%$ of the total area colonized ( $52 \%$ green algae, $4 \%$ cyanobacteria, $44 \%$ heterotrophs). Bioerosion rates in treatments with added inorganic nutrients $\left(396 \mathrm{~g} \mathrm{CaCO}_{3} \mathrm{~m}^{-2} \mathrm{yr}^{-1}\right.$ in the $\mathrm{N}+\mathrm{P}$ treatment and $370 \mathrm{~g} \mathrm{CaCO}_{3} \mathrm{~m}^{-2} \mathrm{yr}^{-1}$ in the $\mathrm{N}+\mathrm{P}+\mathrm{OM}$ treatment) were 9 -fold greater than bioerosion rates in the control and $\mathrm{OM}$ treatments $\left(43\right.$ and $48 \mathrm{~g} \mathrm{CaCO}_{3} \mathrm{~m}^{-2}$ $\mathrm{yr}^{-1}$, respectively), and were not affected by OM addition. We conclude that inorganic nutrients are a major factor controlling the microbioerosion rates and the abundance of euendolithis algae over fungi in carbonate substrata. Microborers act in synergy with the grazers
\end{abstract}

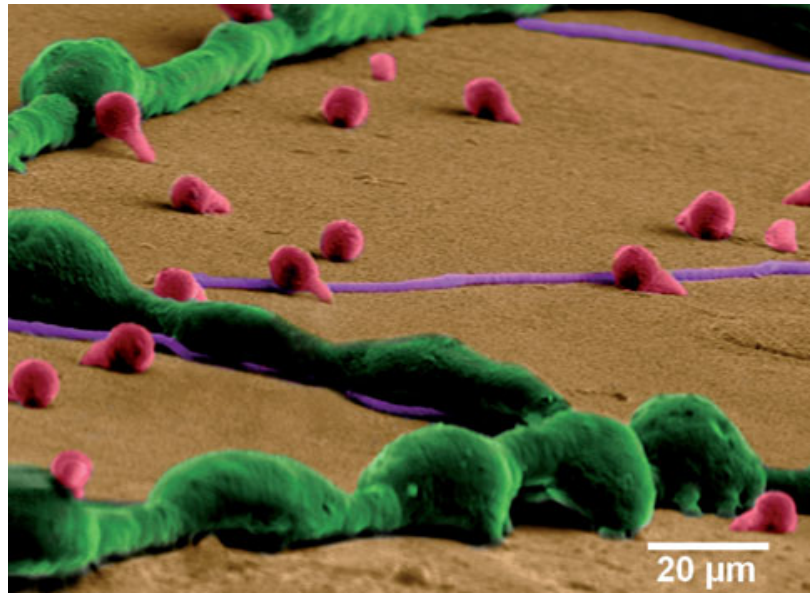

Colored SEM image of microborings made by the green alga Phaeophila sp. (green), and the fungi Dodgella priscus (red) and Ostracoblabe implexa (purple). Borings within mollusc shell were filled with resin and the substratum was then dissolved in acid.

Image: M. Carreiro-Silva, R. Sá da Bandeira

that feed on them and with macroborers that increase the internal surfaces available for microborers to colonize. As a result, increased nutrients can initiate a feedback loop where bioerosion processes reinforce one another, leading to accelerated erosion of the reef framework.

KEY WORDS: Calcium carbonate balance Coral reefs · Microbial euendoliths $\cdot$ Nitrogen $\cdot$ Pollution $\cdot$ Phosphorus · Water quality 


\section{INTRODUCTION}

Degradation of coral reefs is often related to nutrient enrichment associated with increased agriculture activity and urbanization near coastal areas (McClanahan 2002, Szmant 2002, Fabricius 2005). Disturbances from nutrients and organic matter (OM) enrichment include shifts in coral- to algal-dominated reefs (Abram et al. 2003, Lapointe et al. 2004), decreased recruitment and growth of corals (Kinsey \& Davies 1979, Tomascik 1991, Ferrier-Pagés et al. 2000, Ward \& Harrison 2000), higher incidence of coral diseases (Harvell et al. 1999, Kuta \& Richardson 2002, Bruno et al. 2003), increased macroborer abundance (Highsmith 1980, Rose \& Risk 1985, Sammarco \& Risk 1990, Risk et al. 1995, Holmes et al. 2000, Ward-Paige et al. 2005), and reduced reef accretion rates (Hallock 1988, Edinger et al. 2000). Elevated inorganic nutrients (e.g. phosphate, nitrate, nitrite, ammonia) have often been suggested to be the major cause of these disturbances; however, experimental support of this claim remains controversial (reviewed by Szmant 2002), and OM or other unmeasured toxins may often be responsible for some observed coral mortality (Jones \& Kerswell 2003, Kuntz et al. 2005).

Although toxic pollutants are important locally, OM is a globally important constituent of pollution of nearshore coral reefs because most of the nutrients are discharged to the sea in particulate form (e.g. dead and decaying plants; human and animal waste) (Fabricius 2005). Furthermore, much of the dissolved inorganic nutrients can be taken up and converted into particulate forms within hours to days (Furnas et al. 2005). This issue prompted an experimental study of the combined effects of $\mathrm{OM}$ and inorganic nutrients on fish, algae, and coral condition at Glovers Atoll, Belize (McClanahan et al. 2005). Here, we report the results from investigations on nutrient effects on the microbial euendolithic community composition and their bioerosion rates within the same fertilization experiment.

Microbial euendoliths (mainly bacteria, fungi, and algae) are common inhabitants of carbonate substrata in temperate and tropical marine environments (Golubic et al. 1975, Perkins \& Tsentas 1976, Budd \& Perkins 1980, Highsmith 1981, Chazottes et al. 1995, Le Campion-Alsumard et al. 1995, Vogel et al. 2000, Chazottes et al. 2002, Golubic \& Schneider 2003, Tribollet \& Golubic 2005, Tribollet 2008a). Experimental work in tropical settings has demonstrated that microbial euendoliths, or microborers, are important agents of bioerosion, involved in the breakdown of skeletal material (Chazottes et al. 1995, 2002, Tribollet et al. 2002, Carreiro-Silva et al. 2005, Tribollet \& Golubic 2005), limestone coastal erosion (Schneider \& Torunski 1983, Radtke et al. 1996), and erosion of loose carbon- ate sediment grains (Tudhope \& Risk 1985). Microbial euendolithic organisms colonize substrata more rapidly than any other group of bioeroders, representing the first bioerosion process to occur (within 4 to $9 \mathrm{~d}$ ) on newly exposed carbonate substrata (Golubic et al. 1975, Perkins \& Tsentas 1976, Kobluk \& Risk 1977, Tudhope \& Risk 1985, Vogel et al. 2000).

Under natural conditions, the early microborer community in shallow water habitats (1 to $20 \mathrm{~m}$ ) is dominated by the pioneer short-lived green alga Phaeophila sp. (Kiene et al. 1995, Gektidis 1999, Vogel et al. 2000, Carreiro-Silva et al. 2005). This community is then slowly replaced after 3 mo by low-light specialists such as the green alga Ostreobium quekettii and the cyanobacterium Plectonema terebrans, which are able to grow under the reduced light conditions caused by epilithic algal overgrowth and in deeper parts of the substrata (Vogel et al. 2000). A mature microborer community dominated by $O$. quekettii and $P$. terebrans typically occupies substrata after $>1$ yr (Chazottes et al. 1995, Le Campion-Alsumard et al. 1995, Gektidis 1999, Tribollet \& Golubic 2005). Euendolithic heterotrophic fungi and bacteria depend upon a usable source of OM for food. They feed on the organic matrix of substrata, such as shells and skeletal bioclasts, and on algae (Golubic et al. 2005). Thus, heterotrophs are usually slow to colonize substrata and become more abundant as euendolithic algal colonization increases (Kiene et al. 1995, Gektidis 1999, Vogel et al. 2000).

Results from our previous fertilization-herbivory experiment in Belize indicated that bioerosion rates by microborers were enhanced nearly 10 -fold by fertilization, but were reduced by half with the inclusion of herbivores (Carreiro-Silva et al. 2005). However, that study did not investigate the role of $\mathrm{OM}$, another ubiquitous component of eutrophication. Here, we examined the combined effects of inorganic nutrients and OM fertilization and hypothesized that the addition of OM would change the microborer community structure from an autotrophic- to a heterotrophic-dominated community. OM was hypothesized to interact with inorganic nutrients by releasing heterotrophs from carbon limitation and by decreasing the light available (through increased water turbidity and particle settlement on substrata) to euendolithic autotrophs.

\section{MATERIALS AND METHODS}

Study site. This study was conducted at Glovers Reef, Belize, from June to August 2002. The reef is a coral-rimmed atoll, $32 \mathrm{~km}$ long and $12 \mathrm{~km}$ wide, located approximately $45 \mathrm{~km}$ off mainland Belize (Fig. 1a). Experimental substrata were placed at $2 \mathrm{~m}$ depth on the windward side of a patch reef in the Con- 

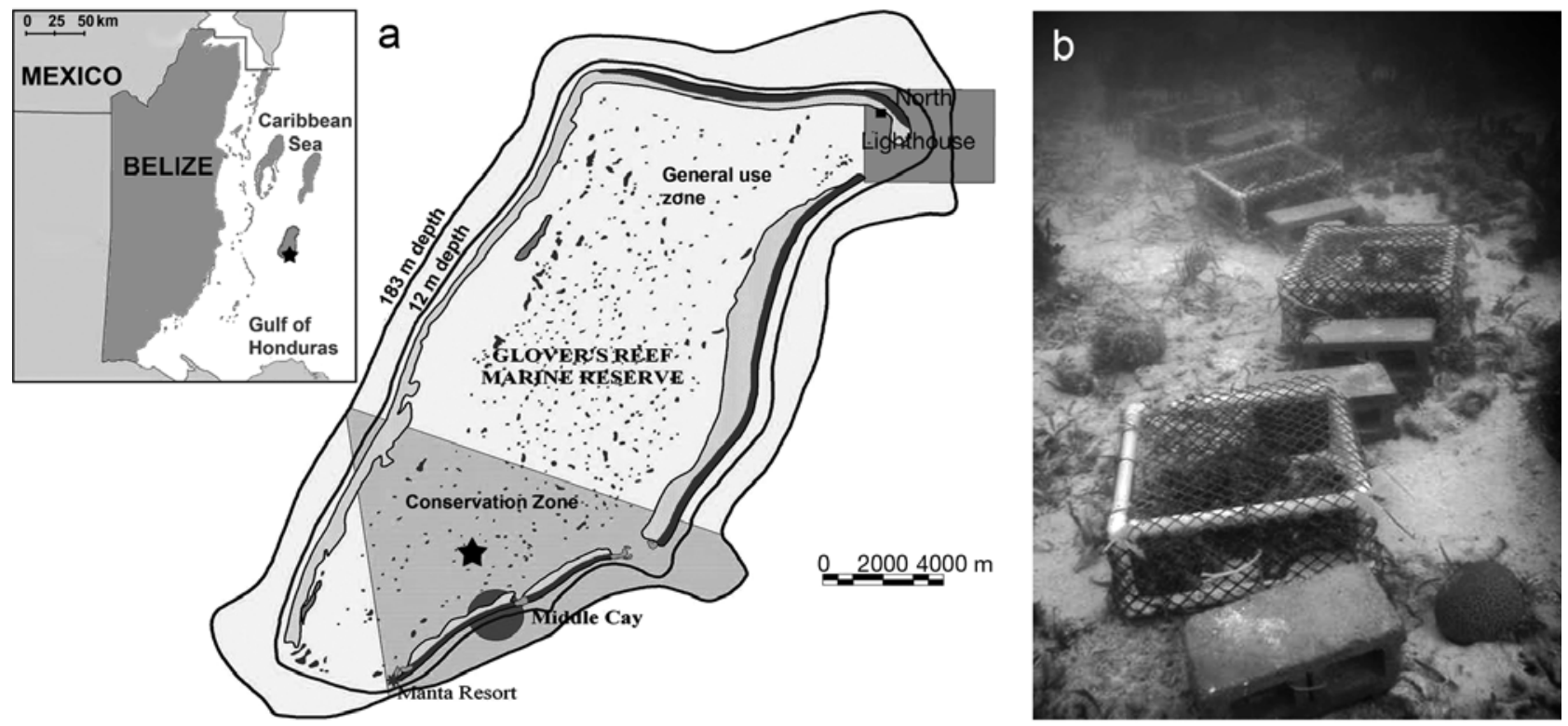

Fig. 1. (a) Geographic location of the experimental site (

) at Glovers Reef, Belize. (b) Closed cages used in the experiment

servation Zone of the atoll's lagoon, where resource extraction is prohibited. The reef is remote and experiences no significant local organic pollution apart from seasonal inputs from distant rivers into this larger oceanic region (Cherubin et al. 2008). The waters in this area are calm with a small $(<0.5 \mathrm{~m})$ tidal range and slow currents $\left(<1 \mathrm{~m} \mathrm{~s}^{-1}\right)$. No large waves or other physical disturbances such as hurricanes were experienced during the study period.

Experimental design. A factorial experimental design was used with closed cages to test for the effects of $\mathrm{OM}$ and inorganic nutrients and their interactions over a $49 \mathrm{~d}$ period. The factors studied were inorganic nutrients $(\mathrm{N}+\mathrm{P})$ and $\mathrm{OM}$ in a 4 treatment structure: (1) a control treatment without fertilizer addition, representing environmental background conditions; (2) an OM treatment, consisting of untreated fine wood dust placed in a mesh nylon bag (mosquito netting) beneath the cages; (3) an inorganic nutrients treatment $(\mathrm{N}+\mathrm{P})$ consisting of inorganic fertilizer spread beneath the cages; and (4) an inorganic nutrients and $\mathrm{OM}$ treatment $(\mathrm{N}+\mathrm{P}+\mathrm{OM})$. In this later treatment, the fertilizer was added to the wood dust inside the same mesh bag. Sixteen cages $(50 \times 50 \times$ $20 \mathrm{~cm}$ ), using 4 cages per treatment, were constructed with PVC frames and $3 \mathrm{~cm}$ mesh plastic caging material (Fig. 1b). Cages were tied to cement masonry blocks that kept them solidly on the reef bottom. The cage mesh size allowed for good water flow and light penetration, and conditions in the cage were expected to resemble natural substrata. Nevertheless, results of actual bioerosion rates should be interpreted with caution due to possible caging effects.
Experimental substrata were made of Strombus gigas mollusc shells. Shells were used instead of coral blocks because their less porous structure produces better casts of boring organisms (Vogel et al. 2000). This improves identification of boring traces, as well as measurements of abundance and depth of penetration used for bioerosion rate estimates. In addition, blocks made of live coral often contain pre-existing traces of boring algae and fungi (Le Campion-Alsumard et al. 1995), which may compromise estimates of microborer surface colonization and bioerosion rates due to treatment effects. By using undamaged interior parts of shells in the present study, artefacts due to pre-existing microborings were avoided. There are differences in the density of coral skeletons and mollusc shells; therefore, bioerosion rate estimates for shells may not correspond to rates for corals. However, the objective of the study was to investigate how inorganic nutrients and OM interact and affect microbioerosion of carbonate substrata by comparing species composition and bioerosion rates between treatments, and not to determine absolute bioerosion rates.

Two pieces $(\sim 12 \times 6 \times 1 \mathrm{~cm}$, length $\times$ width $\times$ thickness) of Strombus gigas shell fragments were placed in each cage, for a total of 8 replicate shell samples exposed to each of the 4 treatments. Shell fragments were fixed to cages by drilling a hole in each of the conch shell pieces and attaching them to the bottom of the cages with black plastic cable ties such that the shell interiors were facing upward. Cages were placed $>1 \mathrm{~m}$ apart, in a line aligned $90^{\circ}$ to the dominant current direction such that neighbouring cages would not slow the currents experienced by the cages and fertil- 
izer would not influence the non-fertilized treatments. Wire brushes were used to clean all cages of algae and other settling organisms every other day to reduce artefacts due to caging such as decreased light and obstruction of local water flow associated with increased algal growth on the mesh of cages. Care was taken not to touch fertilization bags during cleaning of cages to avoid contamination among treatments.

Cages excluded large herbivorous fishes and large predators, but allowed small fishes, such as damselfishes Stegastes spp., wrasses (Labridae), and small parrotfish Sparisoma aurofrenatum and Scarus inserti, to enter and forage (McClanahan et al. 2005). Additionally, the experimental site was uninhabited by sea urchins and not affected by their foraging. No gastropods or crustaceans were observed inside cages throughout the experiment. The number of damselfish, parrotfish, and wrasses that occupied each cage was counted 3 times during the study period over a $3 \mathrm{~min}$ period, and these data were presented by McClanahan et al. (2005).

Nutrient enrichment and sampling. The inorganic fertilizer consisted of $1.5 \mathrm{~kg}$ Scott's slow-release fertilizer, which was spread evenly beneath the cages (as described by Carreiro-Silva et al. 2005), such that each fertilized cage received a dose of $500 \mathrm{~g} \mathrm{P}_{2} \mathrm{O}_{5}, 215 \mathrm{~g}$ ammonium, and $57.5 \mathrm{~g}$ nitrate at the start of the experiment and again after 1 mo. The OM treatment consisted of $5 \mathrm{~kg}$ of untreated and fine sawdust collected from a sander at a local carpenter's workshop. Some fertilizer still remained beneath the cages at the time of re-fertilization after $1 \mathrm{mo}$, suggesting that the original fertilizer was still diffusing out when it was replenished.

Water samples from each cage were collected $1 \mathrm{wk}$ after the first fertilizer addition and $1 \mathrm{wk}$ before the end of the experiment, such that 32 water samples were taken balanced between the 4 treatments. Samples were taken from each cage by opening 100 and $500 \mathrm{ml}$ acid-washed Nalgene bottles approximately $1 \mathrm{~cm}$ above the surface of the substratum. Concentrations of inorganic nitrate/nitrogen and phosphate/phosphorus and suspended solids were measured on the same day with a Hach DR/2500 spectrophotometer using the cadmium reduction method for nitrate and the ascorbic acid method for phosphorus (Parsons et al. 1984). These data were presented by McClanahan et al. (2005).

Sample preparation. Immediately after collection from the cages, shell fragments were fixed in $4 \%$ formaldehyde in seawater solution. Epilithic algal communities on shells ( $\mathrm{n}=8$ per treatment) were studied by taking photographs of the shell's upper surface and estimating the percent surface area covered by different algal groups (turfs, crustose coralline algae, and macroalgae) using the image analysis software ImageJ (available at the National Institute of Health website).
Two approaches were used to document the composition and abundance of microbial euendoliths in each treatment: (1) casts of the boring traces in the experimental samples were observed under scanning electron microscopy (SEM) to provide documentation of the microbial euendoliths' community composition and abundance, allowing the quantification of their bioerosion rates, and (2) observation of microbial euendoliths under light microscopy for detailed identification and confirmation of organisms that produce the traces seen in the SEM casts.

Casts were prepared by cutting and trimming two $1 \mathrm{~cm}^{3}$ cubes from the middle portion of each shell fragment with a diamond-blade rock saw. The area around the hole drilled for fixing shells to cages and the edges of shells were carefully avoided during sample preparation because shell damage may facilitate penetration by euendoliths (Kaehler 1999). Organic remains in samples were dissolved with sodium hypochlorite for $24 \mathrm{~h}$, rinsed with distilled water, and dried overnight at $50^{\circ} \mathrm{C}$. Dried samples were impregnated with epoxy resin (araldite) under vacuum (modified after Golubic et al. 1970). Embedded shell pieces were sawn along their longitudinal axes and placed in a solution of hydrochloric acid $(5 \% \mathrm{HCl})$ to eliminate the shell carbonate matrix and expose the boring trace casts. Casts of shells used in the experiment and casts of unexposed shells were investigated by SEM. Examination of unexposed shell fragments $(\mathrm{n}=8)$ confirmed that there were no borings prior to the experiment. Eight shell samples per treatment and two $1 \mathrm{~cm}^{3}$ subsamples per shell were analyzed.

In order to investigate the organism by light microscopy, the soft epilithic overgrowth of shell pieces $(\mathrm{n}=$ 20) was removed under a dissecting microscope and diluted $\mathrm{HCl}$ was used to dissolve the remaining calcareous incrustation (coralline algae) and substratum. The emerging microbial endoliths were mounted on microscope slides and examined with a Leica DM6000 digital microscope by the differential interference contrast (DIC) method at 400 to $1000 \times$ magnification.

Because the identification of microbial euendolithic organisms and the quantification of bioerosion rates were based on the morphology of the boring traces, a dual system of taxonomic nomenclature was used: ichnotaxonomy was applied for the morphological classification of the traces and biological nomenclature was used for classifying the euendolithic organisms that produced the traces. For example, the boring trace Eurygonum nodosum is generally assumed to be produced by the cyanobacterium Mastigocoleus testarum (Radtke 1993; Fig. 2a,b). The names and identification of the microbial organisms and their boring casts followed descriptions by Le Campion-Alsumard (1979), Radtke (1993), Radtke \& Golubic (2005) and Wissak et 

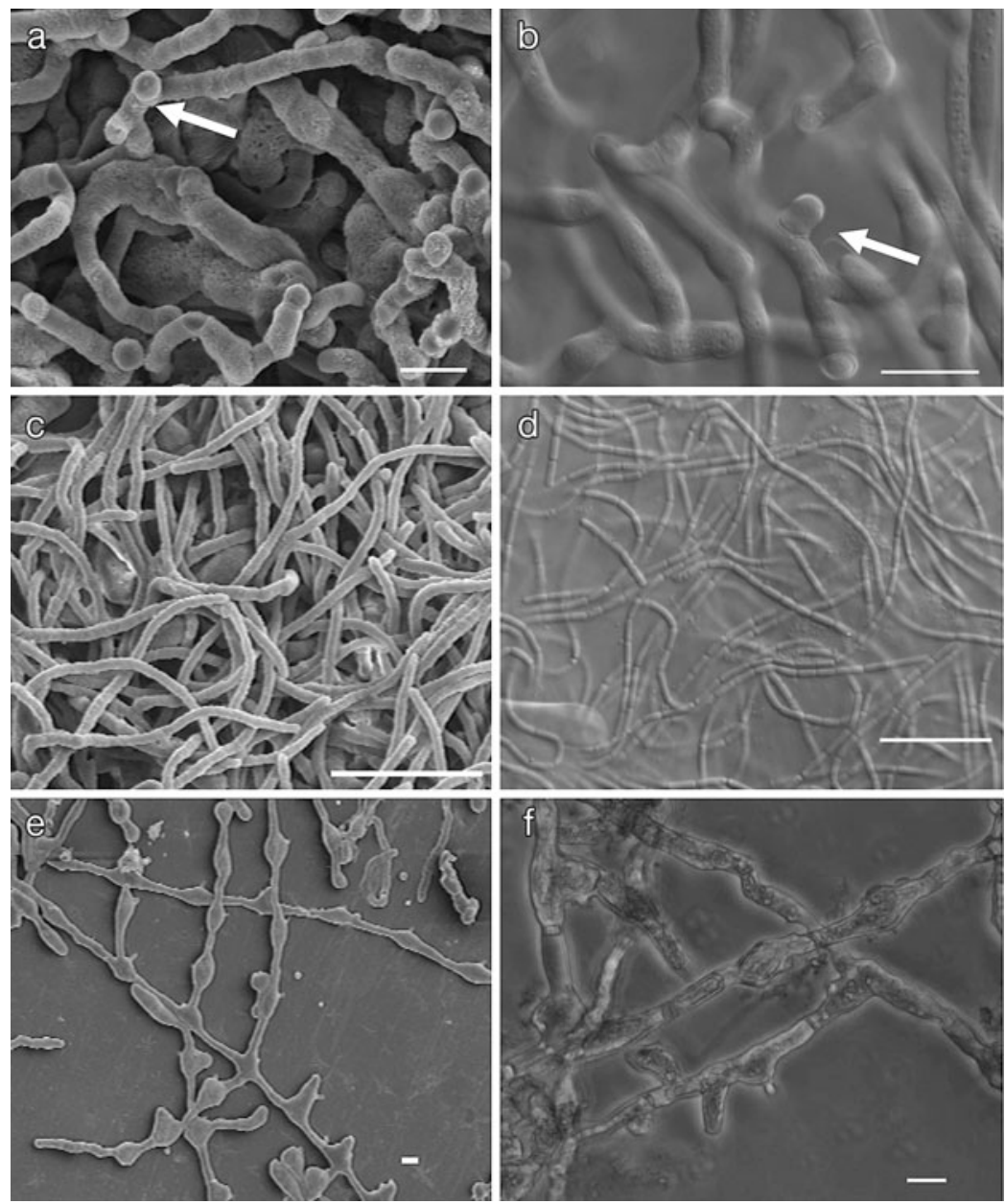

Fig. 2. $(\mathrm{a}, \mathrm{c}, \mathrm{e})$ Scanning electron microscopy image of traces produced by boring phototrophic microorganisms and $(\mathrm{b}, \mathrm{d}, \mathrm{f})$ differential interference contrast images of corresponding euendolithic producers observed in Strombus gigas shells exposed at $2 \mathrm{~m}$ depth, Glovers Reef, Belize, for $49 \mathrm{~d}$. (a) Boring trace Eurygonum nodosum; $_{i}(\mathrm{~b})$ corresponding producer, the cyanobacterium Mastigocoleus testarum (note the heterocysts, arrow); (c) boring trace Scolecia filosa; (d) corresponding producer, the cyanobacterium Plectonema terebrans; (e) boring trace Rhopalia catenata; (f) corresponding producer, the chlorophyte Phaeophila sp. Scale bar $=20 \mu \mathrm{m}$

al. (2005). The proposed changes (Radtke \& Golubic 2005) of the name for cyanobacterial traces Hyella and Solentia from Fasciculus Radtke, 1991 to Fascichnus and for traces of the green alga Ostreobium from Reticulina to Ichnoreticulina were adopted.

Bioerosion rates. The resin-cast method described above results in 3-dimensional casts of the tunnel systems produced by euendoliths within the shells. Based on their structure, microboring traces were classified into morphological types (filament networks, spherical chambers, filament clusters). SEM images with several examples of the percent area of the shell inner surface colonized by borings were prepared, and the surface areas of boring traces were carefully measured using ImageJ. These percentage abundance keys were based on keys presented by Flügel (1982) and used in sedimentary geology and the microscopic analysis of grain percentages in rock thin-sections. The percent area colonized by microborers was determined by comparing the SEM images to this key of different abundances (Kiene et al. 1995, Vogel et al. 2000). By comparing these key images to the small areas viewed with the SEM on each sample's inner upper surface, the areas could be rapidly classified as to their type and to the percent area colonized by borings without having to measure these variables for every area observed. The depth of boring was measured in each sample by observing the sides of boring casts under SEM and measuring the height of boring tunnel networks ( $\mathrm{n}=$ 20). Although it is not an absolute measure of bioerosion, the results obtained from this procedure provide an adequate method for comparing relative bioerosion rates between samples and treatments (Vogel et al. 2000).

Abundance of different microborers and rate of microboring was measured by classifying twenty $1 \mathrm{~mm}^{2}$ areas of the $1 \mathrm{~cm}^{2}$ sample's inner upper surface using the keys described above. The volume of calcium carbonate removed by the microborers in each sample was evaluated by multiplying the estimates of the percent area colonized by the boring traces by their depth of penetration. An estimate of the rates of microbioerosion multiplied the volume of calcium carbonate removed by microborers ( $\mathrm{g}$ $\mathrm{cm}^{-2}$ ) by the shell density $\left(2.65 \mathrm{~g} \mathrm{~cm}^{-3}\right)$. Bioerosion rates over the $49 \mathrm{~d}$ experiment were converted to $\mathrm{g} \mathrm{m}^{-2} \mathrm{yr}^{-1}$ to present them in the form most commonly reported in previous studies.

Data analysis. A mixed-model nested analysis of variance (ANOVA) was used to test for the effects of inorganic nutrients and OM and their interaction on bioerosion rates by all microborings and on microborer depth of penetration within the substratum, and to examine the variation in microbioerosion rates and depths of penetration among shells within a treatment (mixed procedure; SAS Institute 2004). Inorganic nutrients and OM were treated as fixed effects, and shells within treatments, as random effects. Fixed effects in the model were tested using the approximate F-tests of this procedure, and the random effect was tested using the variance component approach (Littell et al. 2006). 
The residual variance component was interpreted as the variability among sub-samples within each shell (the basal unit of replication). The percent variation explained by the nested factor relative to the total variation of the random terms was estimated by dividing the variance component of the nested factor by the total variance (shells within treatments variance + residual variance). The analysis was performed on logtransformed data to correct for lack of homogeneity of variance.

Treatment effects on the percent area colonized by epilithic algae (algal turfs and crustose coralline algae) and microboring groups (green algae, cyanobacteria, and heterotrophs) were tested with a nested ANOVA using the generalized linear mixed model 'Proc GLIMMIX' procedure of SAS (SAS Institute 2004, Littell et al. 2006) for proportion data. Predicted values of percent cover were logit-transformed to linearize the data, and models were fit to the data using residual pseudo-likelihood. This generalized lin-

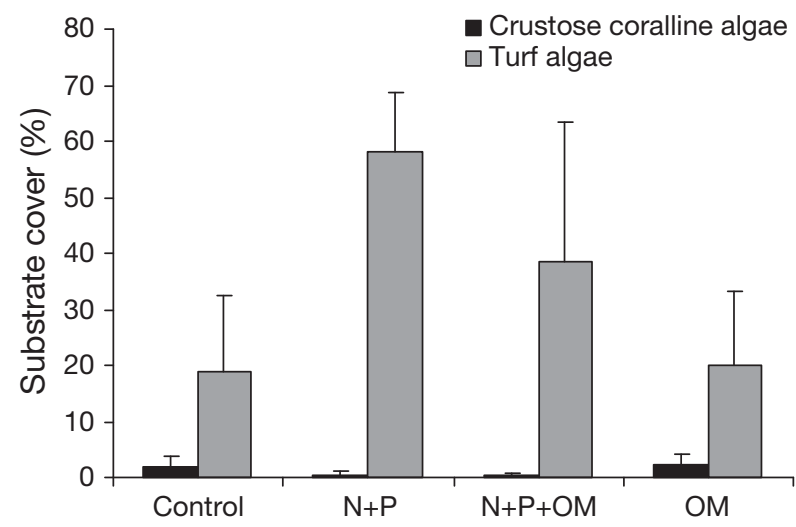

Fig. 3. Epilithic algal cover (mean $\pm \mathrm{SD}$ ) in different treatments on Strombus gigas shells exposed for a period of $49 \mathrm{~d}$. N: nitrogen; P: phosphorus; OM: organic matter ear mixed model procedure assumed a pseudo-binomial error distribution because the data were recorded on a scale from 0 to 1 , and a logit-link function was used (SAS Institute 2004). Fixed and random effects in the model were the same as described above.

Tukey's test (Sokal \& Rohlf 1995) was used to perform post hoc comparisons of means for significant effects. The density and bioerosion rate of 1 sample in the treatment with inorganic fertilizer was 10 standard deviations away from the mean bioerosion rate for that treatment and was, therefore, considered an outlier and removed from the analyses.

\section{RESULTS}

\section{Epilithic algae cover on experimental substrata}

At the end of the experiment, epilithic algal communities on experimental substrata were mainly composed of algal turfs (19 to 58\%; Fig. 3), with less abundance of crustose coralline algae $(<3 \%)$ in all treatments. Brown macroalgae were only recorded in one sample in the control treatment. Both algal turfs and crustose coralline algae were significantly affected by inorganic nutrient addition, but not by OM, with no interaction between the 2 factors (Table 1). Algal turf cover was 2- to 3 -fold greater in the $\mathrm{N}+\mathrm{P}$ and $\mathrm{N}+\mathrm{P}+$ OM treatments $(58 \pm 10.6 \%$ and $39 \pm 24.9 \%$, respectively; mean $\pm \mathrm{SD}$ ) than in the OM and control treatments $(20 \pm 13.3 \%$ and $18.8 \pm 13.7 \%$, respectively; Table 1). In contrast, crustose coralline algal cover was significantly greater in the control and OM treatments $(2.1 \pm 1.6 \%$ and $2.2 \pm 1.2 \%$, respectively $)$ than in the treatments with inorganic nutrient additions $(0.3 \pm$ $0.8 \%$ in $\mathrm{N}+\mathrm{P}$ and $0.4 \pm 0.4 \%$ in the $\mathrm{N}+\mathrm{P}+\mathrm{OM}$ treatments; Fig. 3, Table 1).

Table 1. ANOVA results on the effects of inorganic nutrients $(\mathrm{N}+\mathrm{P})$ and organic matter $(\mathrm{OM})$ additions on epilithic algae (logittransformed means). Results of Tukey test for post hoc comparisons of means are included. C: control treatment; OM: OM treatment; N + P: inorganic nitrogen and phosphorus treatment; N + P + OM: inorganic nitrogen and phosphorus and OM treatment. Note: For random effects, the variance components are reported, while for fixed effects, the $F$-ratios and their probabilities are reported. df: ordinary least-squares degrees of freedom; ${ }^{* * *} \mathrm{p}<0.0001 ;{ }^{* *} \mathrm{p}<0.01 ;{ }^{*} \mathrm{p}<0.05 ;$ ns: not significant

\begin{tabular}{|c|c|c|c|c|c|c|c|c|c|}
\hline Treatment & Effect & $\mathrm{df}$ & Variance component & $F$ & $\mathrm{p}$ & & - & zey test- & \\
\hline \multicolumn{10}{|l|}{ Crustose coralline algae } \\
\hline Inorganic $\mathrm{N}+\mathrm{P}$ & Fixed & 1 & & 9.36 & 0.005 & & $\mathrm{OM}$ & $\mathrm{N}+\mathrm{P}$ & $\mathrm{N}+\mathrm{P}+\mathrm{OM}$ \\
\hline OM & Fixed & 1 & & 0.02 & 0.8800 & $\mathrm{C}$ & ns & * & * \\
\hline Inorganic $\mathrm{N}+\mathrm{P} \times \mathrm{OM}$ & Fixed & 1 & & 0.04 & 0.8343 & OM & & * & * \\
\hline Residual (sub-samples) & Random & 1 & 0.0156 & & & $\mathrm{~N}+\mathrm{P}$ & & & ns \\
\hline \multicolumn{10}{|l|}{ Turf algae } \\
\hline Inorganic $\mathrm{N}+\mathrm{P}$ & Fixed & 1 & & 20.74 & 0.0001 & & $\mathrm{OM}$ & $\mathrm{N}+\mathrm{P}$ & $\mathrm{N}+\mathrm{P}+\mathrm{OM}$ \\
\hline OM & Fixed & 1 & & 1.42 & 0.2430 & $\mathrm{C}$ & ns & ** & * \\
\hline Inorganic $\mathrm{N}+\mathrm{P} \times \mathrm{OM}$ & Fixed & 1 & & 2.08 & 0.1604 & OM & & ** & * \\
\hline Residual & Random & 1 & 0.1304 & & & $N+P$ & & & ns \\
\hline
\end{tabular}


Table 2. Percent surface area covered by microboring traces (ichnotaxa) and their producers (bio-species) in experimental substrata made from Strombus gigas shell and exposed to different treatments for 49 d. Values are means (SD). OM: organic matter treatment; $\mathrm{N}+\mathrm{P}$ : inorganic nitrogen and phosphorus treatment; $\mathrm{N}+\mathrm{P}+\mathrm{OM}$ : inorganic nitrogen and phosphorus and

OM treatment. -: species not recorded in treatment

\begin{tabular}{|c|c|c|c|c|}
\hline Ichnotaxa (bio-species) & Control & $\mathrm{OM}$ & $\mathrm{N}+\mathrm{P}+\mathrm{OM}$ & $\mathrm{N}+\mathrm{P}$ \\
\hline \multicolumn{5}{|l|}{ Cyanobacteria } \\
\hline Scolecia filosa (Plectonema terebrans) & $0.2(0.7)$ & $0.1(0.4)$ & $1.3(2.6)$ & $2.1(2.8)$ \\
\hline Fascichnus dactylus (Hyella caespitosa) & $0.2(0.5)$ & $0.6(0.7)$ & $1.0(2.5)$ & $1.0(2.4)$ \\
\hline Fascichnus frutex (Hyella gigas) & $0.06(0.2)$ & - & $1.0(2.5)$ & $0.02(0.07)$ \\
\hline Fascichnus parvus (Hyella pyxis) & - & $0.1(0.1)$ & - & - \\
\hline Eurygonum nodosum (Mastigocoleus testarum) & $0.7(1.2)$ & $0.1(0.2)$ & $1.0(1.2)$ & $1.8(2.6)$ \\
\hline Planabola isp. (cf. Cyanosaccus piriformis) & & $0.03(0.1)$ & $0.1(0.3)$ & \\
\hline \multicolumn{5}{|l|}{ Green algae } \\
\hline Fascichnus grandis (Acetabularia rhizoid) & $0.03(0.1)$ & - & $0.09(0.2)$ & $0.01(0.04)$ \\
\hline Ichnoreticulina elegans (Ostreobium quekettii) & $0.6(1.9)$ & $0.02(0.07)$ & $0.7(2.0)$ & - \\
\hline Rhopalia catenata (Phaeophila sp.) & $13.3(2.4)$ & $11.7(2.2)$ & $45.8(23.9)$ & $50.9(27.3)$ \\
\hline \multicolumn{5}{|l|}{ Heterotrophs } \\
\hline Saccomorpha sphaerula (Lithopythium gangliiforme) & $1.7(1.8)$ & $5.1(3.4)$ & $1.4(1.9)$ & $1.4(2.8)$ \\
\hline Saccomorpha clava (Dodgella priscus) & $0.5(1.2)$ & $2.3(3.5)$ & $0.4(0.6)$ & - \\
\hline Polyactina araneola (Conchyliastrum enderi) & - & $0.02(0.04)$ & - & - \\
\hline Orthogonum fusiferum (Ostracoblabe implexa) & $0.7(2.5)$ & $1.9(1.1)$ & $1.5(3.6)$ & $0.8(2.1)$ \\
\hline Orthogonum isp. (unknown heterotroph) & - & $0.4(0.1)$ & - & - \\
\hline Total & $18(4)$ & $21.2(3.4)$ & $53.8(22.6)$ & $58.1(25.6)$ \\
\hline
\end{tabular}

\section{Microborers within experimental substrata}

Microborer species composition

A total of 14 different microborer traces were identified in Strombus gigas shells, corresponding to 6 species of cyanobacteria, 3 species of green algae, 4 species of fungi, and 1 unidentified heterotroph (Table 2, Figs. 2, 4 \& 5). Traces by the green alga Phaeophila sp. were the dominant traces in all treatments (from $12 \pm 2$ to $51 \pm 27 \%$; mean \pm

Fig. 4. (a,c,e) Scanning electron microscopy images of traces produced by boring heterotrophic microorganisms and $(\mathrm{b}, \mathrm{d}, \mathrm{f})$ differential interference contrast images of corresponding euendolithic producers observed in Strombus gigas shells exposed at $2 \mathrm{~m}$ depth, Glovers Reef, Belize, for 49 d. (a) Boring trace Saccomorpha spherula (arrow); (b) corresponding producer, the fungus Lithopythium gangliiforme (arrow); (c) boring trace Orthogonum fusiferum (arrow); (d) corresponding producer, the fungus Ostracoblabe implexa; (e) boring trace Orthogonum sp. (unknown producer); (f) boring trace Saccomorpha clava (arrow) produced by the fungus Dodgella priscus (not shown). Scale bars $=10 \mu \mathrm{m}$
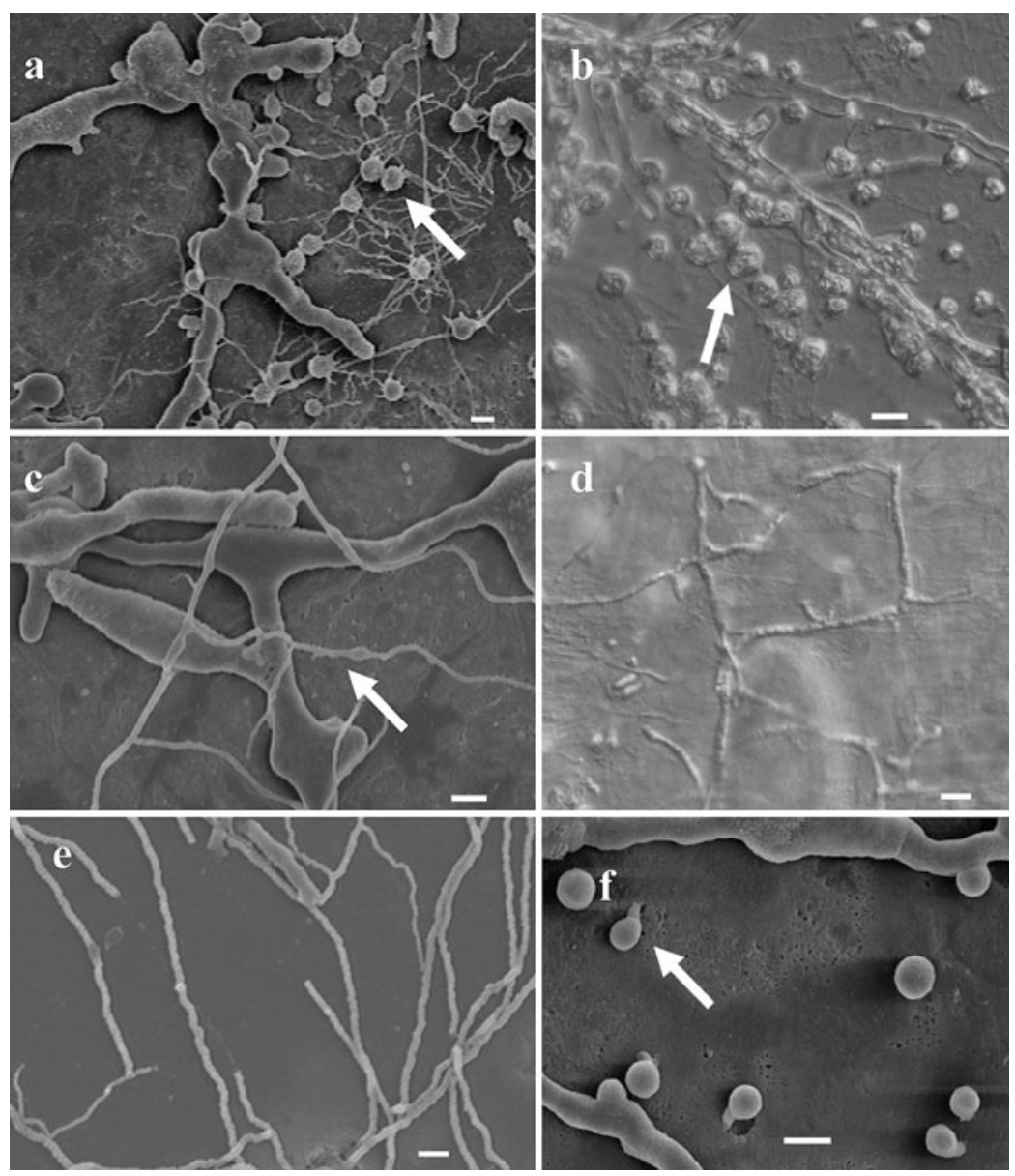

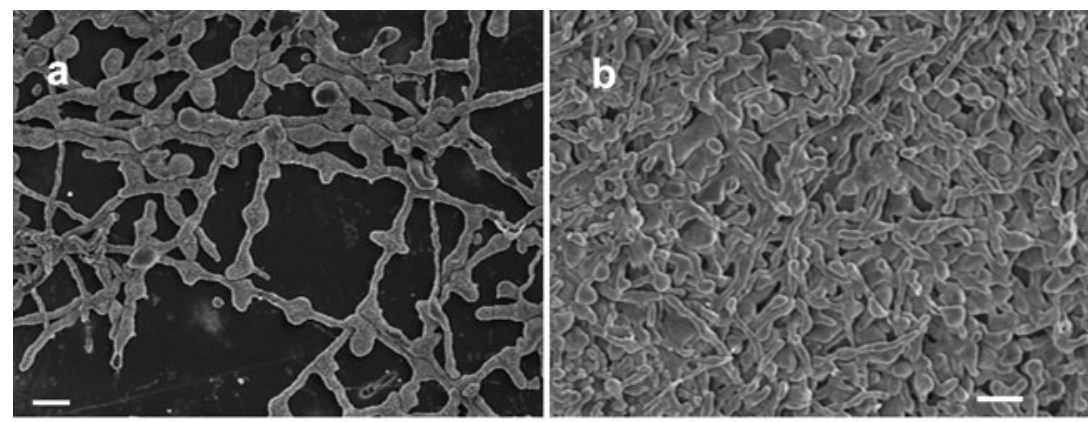

parison with other treatments (Fig. 6a). The area colonized by heterotrophs was not significantly different among any of the other treatments.

An estimation of the variance components for surface area colonized by green algae, cyanobacteria, and heterotrophs indicated that 84 to $98 \%$ of the total variance of the ran-
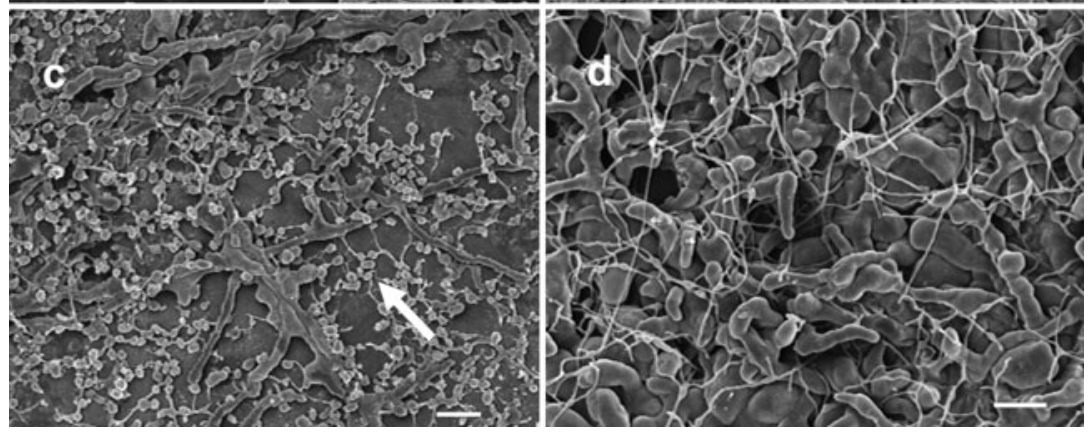

dom terms was due to differences among shells within treatments and 2 to $15 \%$ to differences among subsamples within shells (Table 3).

Differences in euendolithic community composition among treatments were best depicted when surface areas were converted to the relative area colonized (Fig. 6b). Green algal borings dominated the control, $\mathrm{N}+\mathrm{P}$, and $\mathrm{N}+\mathrm{P}+\mathrm{OM}$ treatments ( 77 to $87 \%$ green algae, 6 to $8 \%$ cyanobacteria, 4 to $16 \%$ heterotrophs), whereas in the OM treatment, heterotrophs represented nearly $50 \%$ of the total area colonized (52\% green algae, $4 \%$ cyanobacteria, $44 \%$ heterotrophs).

Fig. 5. Microboring casts of experimental substrata made from Strombus gigas exposed to different treatments at $2 \mathrm{~m}$ depth, Glovers Reef, Belize, for $49 \mathrm{~d}$. (a) Typ ical abundance of boring trace Rhopalia catenata produced by the green alga Phaeophila sp. in the control treatment; (b) boring trace of $R$. catenata in the $\mathrm{N}+\mathrm{P}$ treatment; (c) R. catenata and the boring trace of Saccomorpha spherula (arrow) produced by the fungus Lithopythium gangliiforme in the organic matter (OM) treatment; (d) R. catenata (thick borings) and boring trace of Orthogonum fusiferum produced by the fungus Ostracoblabe implexa (thin filaments) in the $\mathrm{OM}+\mathrm{N}+\mathrm{P}$ treatment. Scale bar $=50 \mu \mathrm{m}$

\section{Microborer species depth of penetration}

SD; Figs. 2e,f \& 5). The second most abundant trace corresponded to the fungus Lithopythium gangliiforme in the OM treatment $(5 \pm 3 \%$; Figs. $4 \mathrm{a}, \mathrm{b} \& 5 \mathrm{c})$. Colonization by other microboring traces was highly variable and generally $<3 \%$.

Total area colonized by all microborers was 3 -fold higher in treatments with added inorganic nutrients $(\mathrm{N}+\mathrm{P}$ and $\mathrm{N}+\mathrm{P}+\mathrm{OM})$ than in other treatments (Tables 2 \& 3). Total area colonized was not significantly different between the $\mathrm{N}+\mathrm{P}$ and $\mathrm{N}+\mathrm{P}+\mathrm{OM}$ treatments or between the control and OM treatments (Table 3). Both green algae and cyanobacteria were affected by the addition of inorganic nutrients and unaffected by the addition of OM (Table 3). These taxa were 4 -fold more abundant in treatments with added inorganic nutrients $(\mathrm{N}+\mathrm{P}$ and $\mathrm{N}+\mathrm{P}+\mathrm{OM})$ than in the control and OM treatments (Tables 2 \& 3, Figs. 5 \& 6a). There was no statistical difference in the area colonized by euendolithic green algae or cyanobacteria between the control and OM treatments.

Heterotrophs were affected by both OM and inorganic nutrients, with no interaction between the 2 factors (Table 3). The addition of OM alone increased colonization by heterotrophs by a factor of 3 in com-
Depths of penetration of euendolithic filaments in experimental shells were significantly greater in treatments with inorganic nutrient additions $(34.6 \pm 11.4 \mu \mathrm{m}$ in $\mathrm{N}+\mathrm{P}$ and $34.8 \pm 6.8 \mu \mathrm{m}$ in the $\mathrm{N}+\mathrm{P}+\mathrm{OM}$ treatments; mean $\pm \mathrm{SD}$ ) than in the $\mathrm{OM}$ and control treatments $(11.6 \pm 3$ and $12.3 \pm 3.2 \mu \mathrm{m}$, respectively; Fig. 7 , Table 3). An estimation of the variance components indicated that $69 \%$ of the total variance of the random terms was due to differences among shells within treatments, and $31 \%$ was due to differences among sub-samples within shells.

\section{Microbioerosion rates}

Microbioerosion rates were significantly affected by the addition of inorganic nutrients, but not by the addition of OM, with no interaction between the 2 factors (Table 3, Fig. 8). Bioerosion rates were nearly 9-fold greater in the $\mathrm{N}+\mathrm{P}$ and $\mathrm{N}+\mathrm{P}+\mathrm{OM}$ treatments $\left(396.4 \pm 54.5\right.$ and $370.3 \pm 38.7 \mathrm{~g} \mathrm{CaCO}_{3} \mathrm{~m}^{-2} \mathrm{yr}^{-1}$, respectively; mean $\pm \mathrm{SE}$ ) than in the control or $\mathrm{OM}$ treatments $\left(43.8 \pm 8.3\right.$ and $48.3 \pm 4.3 \mathrm{~g} \mathrm{CaCO}_{3} \mathrm{~m}^{-2} \mathrm{yr}^{-1}$, 
Table 3. Two-way nested ANOVA on the effects of inorganic nutrients $(\mathrm{N}+\mathrm{P})$ and organic matter (OM) additions on logit-transformed mean surface area cover $(\%)$, depth of penetration $(\mu \mathrm{m})$ and bioerosion rates $\left(\mathrm{g} \mathrm{CaCO}_{3} \mathrm{~m}^{-2} \mathrm{yr}^{-1}\right)$ by all microborers. Results of Tukey test for post hoc comparisons of means are included. C: control treatment; OM: OM treatment; N + P: inorganic nitrogen and phosphorus treatment; $\mathrm{N}+\mathrm{P}+\mathrm{OM}$ : inorganic nitrogen and phosphorus and OM treatment. Note: For random effects, the variance components are reported, while for fixed effects, the F-ratios and their probabilities are reported. df: ordinary least-squares degrees of freedom; ${ }^{* * *} \mathrm{p}<0.0001 ;{ }^{* *} \mathrm{p}<0.01 ;{ }^{*} \mathrm{p}<0.05$; ns: not significant

\begin{tabular}{|c|c|c|c|c|c|c|c|c|c|}
\hline \multirow[b]{2}{*}{ Total } & \multirow[t]{2}{*}{ Effect } & \multirow[t]{2}{*}{$\mathrm{df}$} & \multirow[t]{2}{*}{ Variance component } & \multirow[t]{2}{*}{$F$} & \multirow[t]{2}{*}{$\mathrm{p}$} & \multicolumn{4}{|c|}{$\longrightarrow$ Tukey test } \\
\hline & & & & & & & & & \\
\hline Inorganic $\mathrm{N}+\mathrm{P}$ & Fixed & 1 & & 37.2 & $<0.0001$ & & $\mathrm{OM}$ & $N+P$ & $\mathrm{~N}+\mathrm{P}+\mathrm{OM}$ \\
\hline $\mathrm{OM}$ & Fixed & 1 & & 0.01 & 0.9221 & $\mathrm{C}$ & ns & $* * *$ & $* * *$ \\
\hline Inorganic $\mathrm{N}+\mathrm{P} \times \mathrm{OM}$ & Fixed & 1 & & 0.71 & 0.4082 & OM & & $* * *$ & *** \\
\hline Shell (treatment) & Random & 17 & 0.552 & & & $\mathrm{~N}+\mathrm{P}$ & & & ns \\
\hline Residual (sub-samples) & Random & 32 & 0.024 & & & & & & \\
\hline \multicolumn{10}{|l|}{ Green algae } \\
\hline Inorganic $\mathrm{N}+\mathrm{P}$ & Fixed & 1 & & 47.68 & $<0.0001$ & & $\mathrm{OM}$ & $N+P$ & $\mathrm{~N}+\mathrm{P}+\mathrm{OM}$ \\
\hline $\mathrm{OM}$ & Fixed & 1 & & 0.44 & 0.5145 & $\mathrm{C}$ & ns & $* * *$ & $* * *$ \\
\hline Inorganic $\mathrm{N}+\mathrm{P} \times \mathrm{OM}$ & Fixed & 1 & & 2.03 & 0.7938 & $\mathrm{OM}$ & & $* * *$ & $* * *$ \\
\hline Shell (treatment) & Random & 22 & 0.3208 & & & $N+P$ & & & ns \\
\hline Residual & Random & 32 & 0.01167 & & & & & & \\
\hline \multicolumn{10}{|l|}{ Cyanobacteria } \\
\hline Inorganic $\mathrm{N}+\mathrm{P}$ & Fixed & 1 & & 23.64 & $<0.0001$ & & $\mathrm{OM}$ & $\mathrm{N}+\mathrm{P}$ & $\mathrm{N}+\mathrm{P}+\mathrm{OM}$ \\
\hline $\mathrm{OM}$ & Fixed & 1 & & 0.47 & 0.4982 & $\mathrm{C}$ & ns & ** & $* *$ \\
\hline Inorganic $\mathrm{N}+\mathrm{P} \times \mathrm{OM}$ & Fixed & 1 & & 0.01 & 0.9082 & OM & & $* * *$ & $* * *$ \\
\hline Shell (treatment) & Random & 9 & 0.4388 & & & $\mathrm{~N}+\mathrm{P}$ & & & ns \\
\hline Residual (sub-samples) & Random & 37 & 0.0086 & & & & & & \\
\hline \multicolumn{10}{|l|}{ Heterotrophs } \\
\hline Inorganic $\mathrm{N}+\mathrm{P}$ & Fixed & 1 & & 5.91 & 0.0220 & & $\mathrm{OM}$ & $\mathrm{N}+\mathrm{P}$ & $\mathrm{N}+\mathrm{P}+\mathrm{OM}$ \\
\hline $\mathrm{OM}$ & Fixed & 1 & & 10.6 & 0.0030 & $\mathrm{C}$ & ** & ns & NS \\
\hline Inorganic $\mathrm{N}+\mathrm{P} \times \mathrm{OM}$ & Fixed & 1 & & 2.26 & 0.1686 & OM & & $* * *$ & ** \\
\hline Shell (treatment) & Random & 2 & 0.121 & & & $\mathrm{~N}+\mathrm{P}$ & & & ns \\
\hline Residual (sub-samples) & Random & 32 & 0.023 & & & & & & \\
\hline \multicolumn{10}{|l|}{ Depth of penetration } \\
\hline Inorganic $\mathrm{N}+\mathrm{P}$ & Fixed & 1 & & 141.8 & $<0.0001$ & & $\mathrm{OM}$ & $\mathrm{N}+\mathrm{P}$ & $\mathrm{N}+\mathrm{P}+\mathrm{OM}$ \\
\hline $\mathrm{OM}$ & Fixed & 1 & & 2.64 & 0.1157 & $\mathrm{C}$ & ns & **** & $* * *$ \\
\hline Inorganic $\mathrm{N}+\mathrm{P} \times \mathrm{OM}$ & Fixed & 1 & & 0.02 & 0.8897 & $\mathrm{OM}$ & & $* * *$ & $* * *$ \\
\hline Shell (treatment) & Random & 17 & 0.009 & & & $\mathrm{~N}+\mathrm{P}$ & & & ns \\
\hline Residual (sub-samples) & Random & 31 & 0.004 & & & & & & \\
\hline \multicolumn{10}{|l|}{ Bioerosion rates } \\
\hline Inorganic $\mathrm{N}+\mathrm{P}$ & Fixed & 1 & & 133.9 & $<0.0001$ & & $\mathrm{OM}$ & $\mathrm{N}+\mathrm{P}$ & $\mathrm{N}+\mathrm{P}+\mathrm{OM}$ \\
\hline $\mathrm{OM}$ & Fixed & 1 & & 0.31 & 0.5806 & $\mathrm{C}$ & ns & ${ }^{* * *}$ & $* * *$ \\
\hline Inorganic $\mathrm{N}+\mathrm{P} \times \mathrm{OM}$ & Fixed & 1 & & 0.46 & 0.5028 & $\mathrm{OM}$ & & *** & $* * *$ \\
\hline Shell (treatment) & Random & 15 & 0.038 & & & $\mathrm{~N}+\mathrm{P}$ & & & ns \\
\hline Residual (sub-samples) & Random & 31 & 0.023 & & & & & & \\
\hline
\end{tabular}

respectively; mean $\pm \mathrm{SE}$ ). There was no significant difference in bioerosion rates between the control and OM treatment. The difference in microbioerosion rates in shells within treatments accounted for $62 \%$ of the total bioerosion variance in the random terms, whereas $38 \%$ of the total variance was due to differences in sub-samples within shells.

\section{DISCUSSION}

\section{Effectiveness of treatments}

The addition of inorganic nutrients to fertilized treatments effectively increased dissolved nitrogen and phosphorus concentrations 2- to 3-fold higher than levels in controls (McClanahan et al. 2005), and above levels considered normal for coral reefs (Kleypas et al. 1999). Wood dust was used as a source of particulate OM to simulate decaying plant matter. Wood generally has a C:N ratio of from 150 to 1300 and a C:P ratio of from 13000 to 130000 (Mellilo et al. 1984) and is therefore a suitable source of increased particulate carbon and does not contain detectable levels of inorganic nutrients that would confound the experimental design. Inorganic nutrient concentrations measured in seawater from the cages confirmed that there was no elevation of inorganic nutrients in the OM treatment. Wood dust was expected to increase suspended solids and, therefore, water turbidity in the OM treatments. Nevertheless, suspended solids increased the most in treatments with added inorganic nutrients (McClana- 

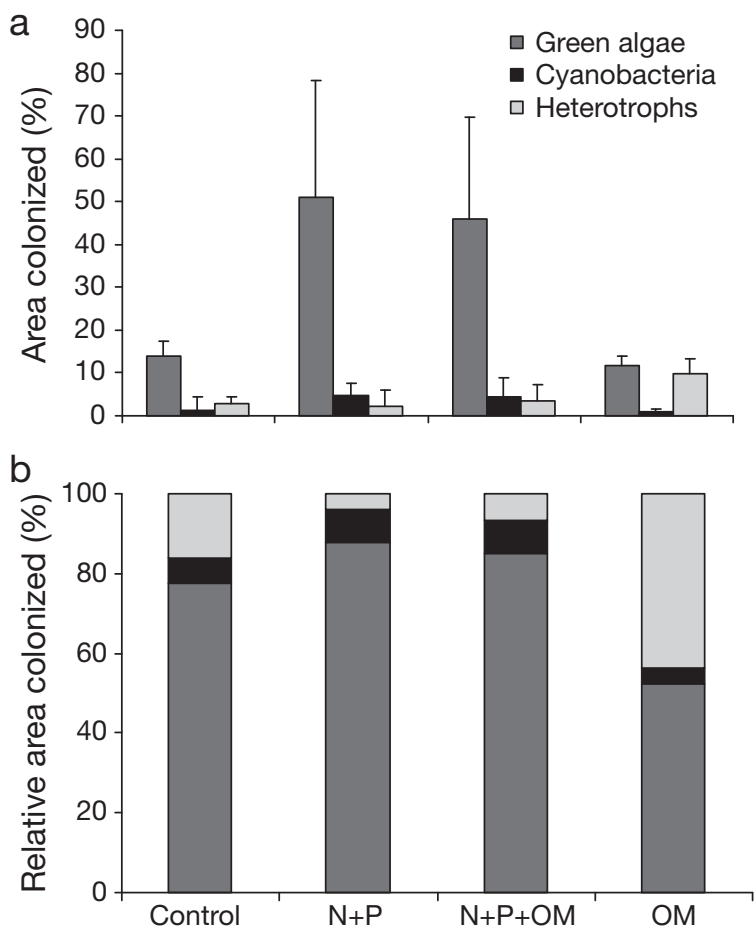

Fig. 6. (a) Inner shell surface area colonized and (b) relative area colonized (mean $\pm \mathrm{SD}$ ) by microborer traces (green algae, cyanobacteria, heterotrophs) exposed to different treatments in Strombus gigas shells for a period of $49 \mathrm{~d}$. $\mathrm{N}$ : nitrogen; P: phosphorus; OM: organic matter

han et al. 2005), suggesting that inorganic nutrients were a stronger factor than $\mathrm{OM}$ for this measure of water quality. Although turbidity was highest in treatments with inorganic nutrients, more wood dust particle deposition was observed on experimental shells in treatments with OM. Particle deposition was also re-

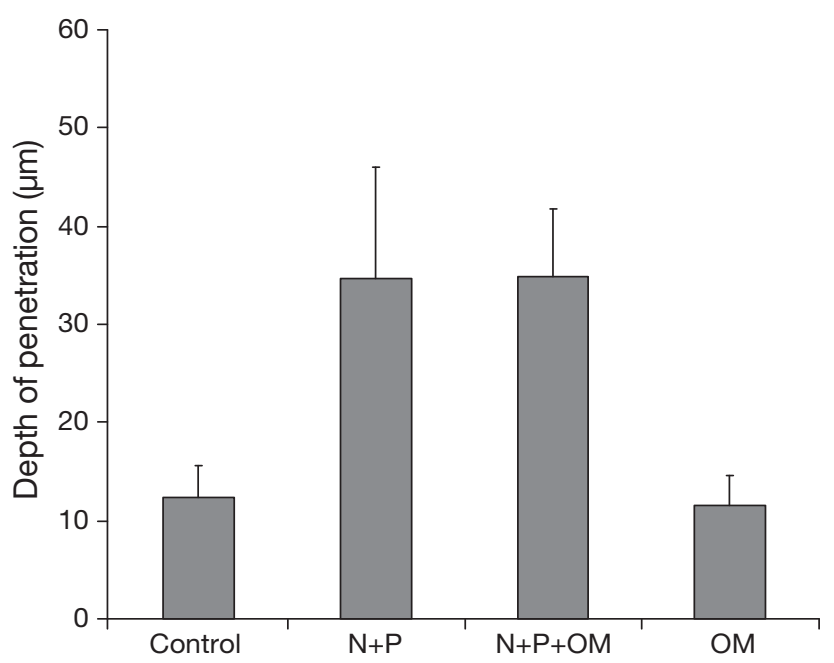

Fig. 7. Depth of penetration (mean $\pm \mathrm{SD}$ ) by all microbial euendoliths exposed to different treatments in Strombus gigas shells for a period of $49 \mathrm{~d}$. N: nitrogen; P: phosphorus; OM: organic matter

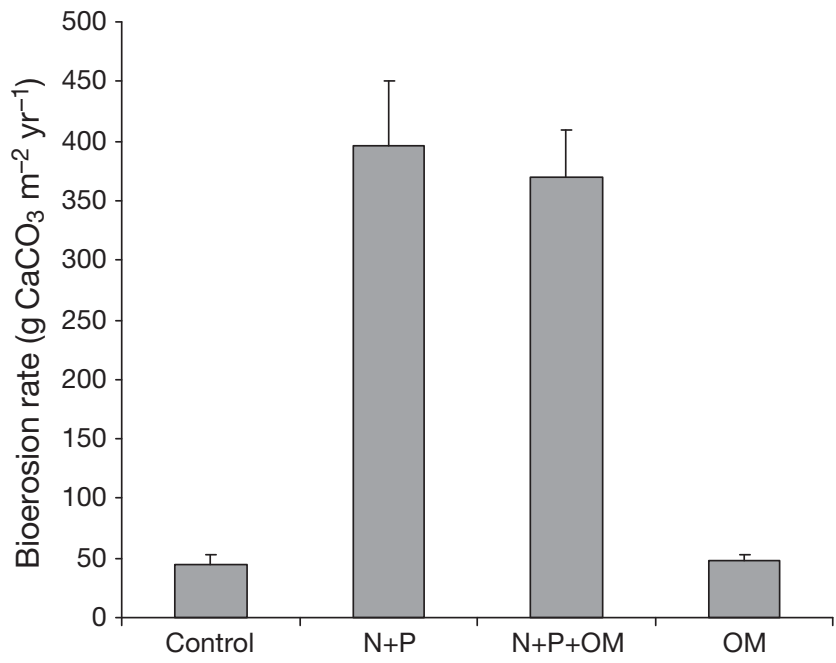

Fig. 8. Bioerosion rates (mean $\pm \mathrm{SE}$ ) by all microbial euendoliths exposed to different treatments in Strombus gigas shells for a period of $49 \mathrm{~d}$. N: nitrogen; P: phosphorus; OM: organic matter

ported on coral plates used as part of the same experimental study (McClanahan et al. 2005).

Closed-top cages were used to minimize the possible effects of large grazers that were previously studied and found to reduce microflora and microbioerosion rates (Carreiro-Silva et al. 2005). Small grazers were able to enter the cages during the experiment, and therefore, herbivory was not entirely excluded. Treatments with added OM had a significantly lower number of damselfishes and parrotfishes entering the cages than other treatments (reported in McClanahan et al. 2005). Parrotfish feed on epilithic and endolithic algae and are important bioeroders themselves (Bellwood 1995, Bruggemann et al. 1996). Nonetheless, because of the small size of the cage mesh $(3 \mathrm{~cm})$, only juvenile parrotfish were able to enter cages and graze on the experimental substrata. Studies of ontogenic changes in parrotfish food selection and food intake have demonstrated that juvenile parrotfish feed mainly on epilithic algae, while larger fish feed increasingly on crustose corallines and endolithic algae (Bruggemann et al. $1994 \mathrm{a}, \mathrm{b})$. Therefore, the lower numbers of juvenile parrotfish in treatments with $\mathrm{OM}$ is unlikely to have affected the studied colonization processes.

\section{Epilithic algal cover on experimental substrata}

The addition of inorganic nutrients increased filamentous turf algae and decreased crustose coralline algae, while OM did not significantly affect algal groups. Brown macroalgae on the experimental shells were only present in one sample in the control treat- 
ment, and therefore appeared unaffected by the addition of inorganic nutrients and OM during this short experiment. Findings are in agreement with reports on previous fertilization studies at Glovers Reef (McClanahan et al. 2002, 2003, 2005, 2007) and elsewhere (Miller et al. 1999, Thacker et al. 2001, Burkepile \& Hay 2006). These studies consistently show that inorganic nutrients increased filamentous turf algae and either did not affect or decreased brown frondose algal colonization and cover. The response of crustose coralline algae to nutrient enrichment experiments has been variable. Studies show no effect (McClanahan et al. 2002, 2003, 2005, 2007), or a negative effect of phosphorus, but a positive effect of nitrate (Bjork et al. 1995). Further studies are needed to clarify the effects of nutrients on coralline algae.

\section{Microborers species composition and depth of penetration}

Organic matter effects

Studies on the development of microboring communities through time (Kiene et al. 1995, Gektidis 1999) have shown that bacteria and fungi are generally slow to colonize newly exposed substratum and become abundant only after 1 yr of exposure. Kiene et al. (1995) suggest that, although heterotrophic endoliths are able to feed on the organic structures that exist in shells, they become abundant only after colonization by autotrophic borers. In the present study, the addition of OM increased the abundance of heterotrophs (in particular fungi), but only when OM was added alone, not when combined with inorganic nutrients. Fungi have high physiological versatility and are able to degrade OM from a variety of substrata (e.g. leaves, wood, sediments, shells, corals; Hyde et al. 1998). We speculate that wood dust particle deposition on experimental shells in the OM treatment may have increased the settlement success of fungal spores and enhanced their abundance. Further investigations are needed to determine the exact mechanism that led to increased abundance of fungi in the OM treatment.

The reasons for lower fungal abundance in the $\mathrm{N}+\mathrm{P}$ + OM than in the OM-alone treatment are unclear, but it may be that that green algae (particularly Phaeophila sp.), when released from nutrient limitation, have more efficient growth or nutrient uptake mechanisms and colonize substrata faster than fungi. Phaeophila sp. is an early boring colonist with a short generation time, and individuals or colonies have a rapid turnover (Kiene et al. 1995). Alternatively, in some of the more densely colonized samples, deep borings of Phaeophila sp. obscured more shallow (close to the surface) borings by fungi, leading to an underestimate of their real abundance. It is possible that, if monitored through time, a slower response of fungi to OM in these treatments may be observed, as fungi hypha penetrate deeper underneath borings of Phaeophila sp. Heterotrophic organisms are reported to grow at greater depths in substrata without organic substances and boring algae to feed on (e.g. fine-grained limestone and calcite: Kiene et al. 1995, Vogel et al. 2000, Wissak et al. 2005). Other factors, apart from nutrient availability, are likely to play an important role in controlling the abundance of heterotrophic organisms, although these have been poorly investigated for carbonate substrata.

The addition of OM did not appear to negatively affect the abundance of euendolithic algae in our experiment. Lower bioerosion rates by microborers on in-shore reef sites with elevated turbidity from suspended sediments were recorded in previous investigations on bioerosion rates along a cross-shelf transect on the northern Great Barrier Reef, Australia (Tribollet et al. 2002, Tribollet \& Golubic 2005). Investigators suggested that these lower rates resulted from reduced light and deposition of particles that inhibit the settlement and growth of autotrophic microbial euendoliths. In our experiment, turbidity was highest in treatments with added inorganic nutrients, where substratum colonization by algae was highest. Differences observed between these studies could be related to higher turbidity levels and higher particle settlement in the Great Barrier study, where coral substrata were exposed for 1 to $4 \mathrm{yr}$, in contrast to only $49 \mathrm{~d}$ in our study.

\section{Inorganic nutrient effects}

The addition of inorganic nutrients increased colonization by green algae 4 -fold above control levels. This result confirms the trends observed by CarreiroSilva et al. (2005) when inorganic nutrients and herbivory were manipulated. The cyanobacteria Plectonema terebrans (Fig. 2c,d) was, however, considerably less abundant in the present experiment $(2.1 \pm 2.8 \%$; mean $\pm \mathrm{SD})$ than in the previous study $(31.7 \pm 13.4 \%)$. High variability in cyanobacteria recruitment into experimental substrata (Kiene et al. 1995) may explain this difference.

The lower abundance of Plectonema terebrans in the $\mathrm{N}+\mathrm{P}$ treatment resulted in lower colonization of shells compared the findings of Carreiro-Silva et al. (2005) $(58.1 \pm 25.6 \%$ as compared with $85.2 \pm 11 \%$; mean \pm $\mathrm{SD})$. Although colonization by different microborer taxa (green algae, cyanobacteria, and heterotrophs) changed significantly in different treatments, the number of species recorded in each treatment varied less. 
The exception was the lower number of fungal species in the $\mathrm{N}+\mathrm{P}$ treatment as compared with other treatments. While OM increased the abundance of fungi, they have small boring traces, and therefore, the green alga Phaeophila sp. was the dominant taxon in all treatments. High colonization by these algae is a characteristic of early boring communities (or a juvenile biocoenosis; Gektidis 1999, Vogel et al. 2000). At this stage of colonization, typically from 30 to $90 \%$ of the bored surface is occupied by Phaeophila sp. (Vogel et al. 2000), which agrees with our findings.

Epilithic algal communities can influence the abundance and composition of euendolithic communities by reducing light conditions and influencing grazers (Gektidis 1999, Vogel et al. 2000, Chazottes et al. 2002). Low-light specialists, such as Plectonema terebrans and Ostreobium quekettii have been observed in association with crustose coralline algae and erect algae in reefs with low grazing (Chazottes et al. 2002), whereas the pioneer species Mastigocoleus testarum have been noted in association with high grazing and cover by epilithic algal turfs (Chazottes et al. 2002, LeBris 2002).

However, in the present study epilithic algal communities did not influence the abundance and composition of euendolithic communities. Algal groups that can produce the greatest reduction in light within substrata, crustose coralline and erect algae, had low cover in all treatments of our study $(<3 \%)$. Algal turfs were composed by thin, sparse, filamentous algae and responded equally strong to inorganic nutrient addition as euendolithic communities, covering from 40 to $60 \%$ of the experimental substrata in the $\mathrm{N}+\mathrm{P}$ and $\mathrm{N}+\mathrm{P}+\mathrm{OM}$ treatments. In addition, the low-light specialists Ostreobium quekettii and Plectonema terebrans were not more abundant in these treatments. The interactions between epilithic and euendolithic communities reported in other studies (e.g. Gektidis 1999, Chazottes et al. 2002) are generally for substrata exposed for $>6$ mo.

Likewise, no changes in the composition of euendolithic communities were observed in treatments with OM. Therefore, the expected light reduction associated with particle deposition in treatments with added $\mathrm{OM}$ was not strong enough to produce changes in the taxonomic composition of microbial euendoliths. Longer experiments with better measures of light penetration into the substrata will be needed to fully describe changes in the succession of species in the microboring community.

Depths of penetration of euendolithic filaments were greatest in treatments with inorganic nutrients, but unaffected by the addition of OM. The higher abundance of green algae (mainly Phaeophila sp.) and cyanobacteria in the inorganic nutrient-enriched treat- ments resulted in higher depths of penetration in these treatments. Phaeophila sp. generally grows parallel to the substratum, but in shells that were intensively bored, such as in the $\mathrm{N}+\mathrm{P}$ and $\mathrm{N}+\mathrm{P}+\mathrm{OM}$ treatments, species' tunnels are generally more slender and penetrate more deeply (Fig. 4b,c). Avoidance of tunnels and passing beneath earlier borings creates this slender morphology (Radtke \& Golubic 2005). Euendolithic penetration depths measured in the present study are within ranges found in other shell substrata $(30 \mu \mathrm{m}$ in Strombus sp., Kiene et al. 1995; and from 25 to $130 \mu \mathrm{m}$ in black pearl oyster, Mao Che et al. 1996). Penetration depths are generally lower in mollusc shells than in coral skeletons (Chazottes et al. 1995, Tribollet 2008b), attributable to greater porosity and translucency of coral substrata (Tribollet 2008a).

Microbial euendoliths in the present study were identified according to morphological descriptions. Although this is traditionally the common method, recent investigations comparing electron microscopy, cultivation, and molecular genetic techniques suggest that morphological descriptions tend to underestimate diversity compared to molecular genetic techniques (Chacón et al. 2006). Therefore, it is possible that diversity was underestimated, particularly of filamentous fungi and cyanobacteria (Golubic et al. 2005, Chacón et al. 2006). Studies that include molecular genetic techniques in the characterization of microbial euendolithic organisms will provide a better understanding of their ecology and phylogenetic relationships, and are a priority for future research (Golubic et al. 2005).

\section{Microbioerosion rates}

Inorganic nutrient additions increased microbioerosion rates by a factor $\sim 9$, while microbioerosion rates were unaffected by the addition of OM. Addition of OM changed the relative abundance of heterotrophs, but did not influence total bioerosion rates. Higher abundance of euendolithic organisms and higher depths of penetration in experimental substrata resulted in higher microbioerosion rates in treatments with inorganic nutrients. Bioerosion rates in the inorganic nutrient treatments were on the same order of magnitude as the rates obtained in our previous low herbivory and fertilized treatment (Carreiro-Silva et al. 2005). The only other previous experimental fertilization manipulation on the Great Barrier Reef (the ENCORE experiment; Kiene 1997, Koop et al. 2001) failed to find a fertilizer effect, probably due to poor fertilization and a lack of control for herbivory (Carreiro-Silva et al. 2005).

Bioerosion rates in the inorganic nutrient-enrichment treatment were comparable to rates measured for 
coral blocks on reefs with low herbivory and nutrient pulses at Moorea Island ( $570 \mathrm{~g} \mathrm{~m}^{-2} \mathrm{yr}^{-1}$; Chazottes et al. 1995, Peyrot-Clausade et al. 1995). Higher bioerosion rates have, however, been measured in coral blocks located on the outer reefs of Australia's Great Barrier Reef, with little or no anthropogenic influence (1001 to $1420 \mathrm{~g} \mathrm{~m}^{-2} \mathrm{yr}^{-1}$; Tribollet et al. 2002, Tribollet \& Golubic 2005). In contrast, low bioerosion rates (57 and $67 \mathrm{~g} \mathrm{~m}^{-2} \mathrm{yr}^{-1}$ ) have been recorded for coral substrata in Reunion Island experiencing $\mathrm{N}$ and $\mathrm{P}$ inputs and low grazing (Chazottes et al. 2002). These values are comparable to the rates obtained in our control treatments. Differences could be related to the use of different substrata (shells versus coral), depth, length of exposure, location, other sources of erosion such as grazing, and the methods used for the quantification of microbioerosion (Kiene et al. 1995, Vogel et al. 2000, Carreiro-Silva et al. 2005). Bioerosion rates here were extrapolated from $49 \mathrm{~d}$ to $1 \mathrm{yr}$, which are the units most commonly reported in previous studies. However, microbioerosion rates do not increase proportionally or linearly in time, but rather are cumulative over time (Tribollet \& Golubic 2005, Tribollet 2008a). Despite the potential shortcomings of our short-term experiment, the experimental nature of the study reduces the many confounding factors that make understanding causation in non-experimental descriptive studies difficult.

Several experimental studies of bioerosion have demonstrated considerable spatial and temporal variations in bioerosion rates by macroboring organisms (Hutchings 1986, Hutchings et al. 1992, 2005). Estimates of variance components associated with shell and sub-sample replicates in our study provide clues about the spatial scales at which euendolithic microorganisms tend to patch. Variability was highest among shells within treatments, suggesting patchy recruitment at this small scale. Similarly, Hutchings et al. (1992) also suggest recruitment variability may be related to factors operating at a very small scale for macroborer larvae, and we suggest this is the case for microborer spores as well.

\section{CONCLUSIONS}

Results of our present and previous (Carreiro-Silva et al. 2005) studies indicate that the addition of inorganic nutrients increases abundances of microboring organisms, in particular green algae and cyanobacteria, and increases bioerosion by a factor of $\sim 9$ compared with controls. Increased particulate OM in reef waters promotes the abundance of euendolithic fungi, but not erosion rates. Results from shells cannot be easily extrapolated to coral substrata, but experiments demonstrate a clear, direct effect of fertilization on increasing microbioerosion of carbonates during the early stages of colonization. Long-term studies have demonstrated that rates of microbioerosion are not linear in time (Chazottes et al. 1995, Tribollet \& Golubic 2005, Tribollet 2008b) and are influenced by ecological conditions such as herbivory (Chazottes et al. 2002, Tribollet et al. 2002, Carreiro-Silva et al. 2005, Tribollet $\&$ Golubic 2005) and epilithic algal cover (Chazottes et al. 2002). Microbial euendoliths promote bioerosion, not only through their own borings, but also by providing a source of food for grazers (Chazottes et al. 2002, Tribollet et al. 2002, Carreiro-Silva et al. 2005, Tribollet \& Golubic 2005). Grazers, such as parrotfish, urchins, and some molluscs, remove substratum surface layers to feed on euendoliths. As the surface is excavated, the depth to which microbial euendoliths can bore is increased. In addition, borings produced by larger endoliths, such as sponges, molluscs, and worms, increase the 3-dimensional habitat available to microborers. Therefore, elevated nutrients in reef waters can initiate a feedback loop in which bioerosion is reinforced by macroboring, and microboring and grazing leading to accelerated erosion of the reef framework. Long-term experiments that manipulate and control for the above factors are likely to produce further insights into the forces influencing bioerosion. Molecular genetic techniques that characterize the phylogeny and ecology of microborer communities are also a priority for future research.

Acknowledgements. This research received financial support from the Wildlife Conservation Society (WCS) (T.R.M.), the Fundação para a Ciência e a Tecnologia, Portugal, and the European Social Fund under the III Communitary Support Board (M.C.S., SFRH/BD/789/2000 and SFRH/BPD/34634/ 2007). We are grateful to the Smithsonian National Museum of Natural History and I. McIntyre and D. Dean for their assistance in preparing samples. S. Jones, R. Steneck, and B. Cokos assisted with the conch shells, cages, and fixing samples. L. W. Douglass provided statistical advice. The thoughtful comments of J. A. Mihursky and V. S. Kennedy improved earlier versions of this manuscript. Permission to undertake the work was provided by the Belize Fisheries Department. This is publication number 33 of the Glovers Reef Research Station.

\section{LITERATURE CITED}

Abram NJ, Gagan MK, McCulloch MT, Chappell J, Hantoro WS (2003) Coral reef death during the 1997 Indian Ocean dipole linked to Indonesian wildfires. Science 301:952-955

Bellwood DR (1995) Direct estimate of bioerosion by two parrotfish species, Chlorurus gibbus and C. sordidus, on the Great Barrier Reef, Australia. Mar Biol 121:419-429

Bjork M, Mohammed SM, Bjorklund M, Semesi A (1995) Coralline algae, important coral-reef builders threatened by pollution. Ambio 24:502-505

> Bruggemann JH, Begeman J, Bosma EM, Verburg P, Breeman AM (1994a) Foraging by the stoplight parrotfish 
Sparisoma viride. II. Intake and assimilation of food, protein, and energy. Mar Ecol Prog Ser 106:57-71

Bruggemann JH, Kuyper MW, Breeman AM (1994b) Comparative analysis of foraging and habitat use by the sympatric Caribbean parrotfish Scarus vetula and Sparisoma viride (Scaridae). Mar Ecol Prog Ser 112:51-66

Bruggemann JH, van Kessel AM, van Rooij JM, Breeman AM (1996) Bioerosion and sediment ingestion by the Caribbean parrotfish Scarus vetula and Sparisoma viride: implications of fish size, feeding mode and habitat use. Mar Ecol Prog Ser 134:59-71

Bruno JF, Petes LE, Harvell CD, Hettinger A (2003) Nutrient enrichment can increase the severity of coral diseases. Ecol Lett 6:1056-1061

Budd DA, Perkins RD (1980) Bathimetric zonation and paleoecological significance of microborings in Puerto Rican shelf and slope sediments. J Sediment Petrol 50:881-904

Burkepile DE, Hay ME (2006) Herbivore vs. nutrient control of marine primary producers: context-dependent effects. Ecology 87:3128-3139

> Carreiro-Silva M, McClanahan TR, Kiene W (2005) The role of nutrients and herbivory in controlling the microbioerosion of carbonate substratum. Coral Reefs 24:214-221

Chacón E, Berrendero E, Garcia Pichel F (2006) Biogeological signatures of microbial cyanobacterial communities in marine carbonates from Cabo Rojo, Puerto Rico. Sediment Geol 185:215-228

Chazottes V, Le Campion-Alsumard T, Peyrot-Clausade M (1995) Bioerosion rates on coral reefs: interactions between macroborers, microborers and grazers (Moorea, French Polynesia). Palaeogeogr Palaeoclimatol Palaeoecol 113:189-198

Chazottes V, Le Campion-Alsumard T, Peyrot-Clausade M, Cuet P (2002) The effects of eutrophication-related alterations to coral reef communities on agents and rates of bioerosion (Reunion Island, Indian Ocean). Coral Reefs 21:375-390

Cherubin LM, Kuchinke CP, Paris CB (2008) Ocean circulation and terrestrial runoff dynamics in the Mesoamerican region from spectral optimization of SeaWiFS data and a high resolution simulation. Coral Reefs 27:503-519

Edinger EN, Limmon GV, Jompa J, Widjatmokos W, Heikoop JM, Risk MJ (2000) Normal coral growth rates on dying reefs: Are coral growth rates good indicators of reef health? Mar Pollut Bull 40:404-425

Fabricius KE (2005) Effects of terrestrial runoff on the ecology of corals and coral reefs: review and synthesis. Mar Pollut Bull 50:125-146

Ferrier-Pagés C, Gattuso JP, Dallot S, Jaubert J (2000) Effect of nutrient enrichment on growth and photosynthesis of the zooxanthellate coral Stylophora pistillata. Coral Reefs 19:103-113

Flügel E (1982) Microfacies analysis of limestones. SpringerVerlag, Berlin

Furnas M, Mitchell A, Skuza M, Brodie J (2005) In the other $90 \%$ : phyotoplankton responses to enhanced nutrient availability in the Great Barrier Reef Lagoon. Mar Pollut Bull 51:253-265

Gektidis M (1999) Development of microbial eueuendolithic communities: the influence of light and time. Bull Geol Soc Den 45:147-148

Golubic S, Schneider J (2003) Microbial endoliths as internal biofilms. In: Krumbein WE, Paterson DM, Zavarzin GA (eds) Fossil and recent biofims. A natural history of life on earth. Kluwer Academic Publishers, Dordrecht, p 249-263

> Golubic S, Brent G, Le Campion-Alsumard T (1970) Scanning electron microscopy of euendolithic algae and fungi using multipurpose casting-embedding technique. Lethaia 3: 203-209

Golubic S, Perkins RD, Lukas KJ (1975) Boring microorganisms and microborings in carbonate substrates. In: Frey RW (ed) The study of trace fossils. Springer-Verlag, Heidelberg, p 229-259

Golubic S, Radtke G, Le Campion-Alsumard T (2005) Euendolithic fungi in marine ecosystems. Trends Microbiol 13:229-235

Hallock P (1988) The role of nutrient availability in bioerosion: consequences to carbonate buildups. Palaeogeogr Palaeoclimatol Palaeoecol 63:275-291

Harvell CD, Kirn K, Burkholder JM, Colwell RR and others (1999) Emerging marine diseases-climate links and anthropogenic factors. Science 285:1505-1510

> Highsmith RC (1980) Geographic patterns of coral bioerosion: a productivity hypothesis. J Exp Mar Biol Ecol 46:177-196

> Highsmith RC (1981) Lime-boring algae in coral skeletons. J Exp Mar Biol Ecol 55:267-281

> Holmes KE, Edinger EN, Hariyadi S, Limmon GV, Risk MJ (2000) Bioerosion of live massive corals and branching coral rubble on Indonesian coral reefs. Mar Pollut Bull 40:606-617

Hutchings PA (1986) Biological destruction of coral reefs. Coral Reefs 4:239-252

Hutchings PA, Kiene WE, Cunningham RB, Donnelly C (1992) Spatial and temporal patterns of non-colonial boring organisms (polychaetes, sipunculans and bivalve mollusks) in Porites at Lizard Island, Great Barrier Reef. Coral Reefs 11:23-31

Hutchings P, Peyrot-Clausade M, Osnorno A (2005) Influence of land runoff on rates and agents of bioerosion of coral substrates. Mar Pollut Bull 51:438-447

Hyde KD, Jones EBG, Leaño E, Pointing SB, Poonyth AD, Vrijmoed LLP (1998) Role of fungi in marine ecosystems. Biodivers Conserv 7:1147-1161

Jones RJ, Kerswell AP (2003) Phytotoxicity of Photosystem II (PSII) herbicides to coral. Mar Ecol Prog Ser 261:149-159

Kaehler S (1999) Incidence and distribution of phototrophic shell-degrading endoliths of the brown mussel Perna perna. Mar Biol 135:505-514

Kiene WE (1997) Enriched nutrients and their impact on bioerosion: results from ENCORE. In: Lessios HA, MacIntyre IG (eds) Proc 8th Int Coral Reef Symp, Vol 1. Smithsonian Tropical Research Institute, Balboa, Panama, p 897-902

Kiene WE, Radtke G, Gektidis M, Golubic S, Vogel K (1995) Factors controlling the distribution of microborers in Bahamian reef environments. In: Schumacher H, Kiene WE, Dullo WC (eds) Factors controlling Holocene reef growth: an interdisciplinary approach. Facies 32:174-188

Kinsey DW, Davies PJ (1979) Effects of elevated nitrogen and phosphorus on coral reef growth. Limnol Oceanogr 24: 935-940

Kleypas JA, McManus JW, Menez LAB (1999) Environmental limits to coral reef development: Where do we draw the line? Am Zool 39:146-159

Kobluk DR, Risk MJ (1977) Rate and nature of infestation of carbonate substrates by a boring alga. J Exp Mar Biol Ecol 27:107-115

Koop K, Booth D, Broadbent A, Brodie J and others (2001) ENCORE: the effect of nutrient enrichment on coral reefs. Synthesis of results and conclusions. Mar Pollut Bull 42: 91-120

> Kuntz NM, Kline DI, Sandin SA, Rohwer F (2005) Pathologies and mortality rates caused by organic carbon and nutrient stressors in three Caribbean coral species. Mar Ecol Prog Ser 294:173-180 
Kuta KG, Richardson LL (2002) Ecological aspects of black band disease of corals: relationships between disease incidence and environmental factors. Coral Reefs 21:393-398

Lapointe BE, Barile PJ, Yentsch CS, Littler MM, Littler DS, Kakuk B (2004) The relative importance of nutrient enrichment and herbivory on macroalgal communities near Norman's Pond Cay, Exumas Cays, Bahamas: a 'natural' enrichment experiment. J Exp Mar Biol Ecol 298: 275-301

Le Bris S, Le Campion-Alsumard T, Romano JC (1998) Characteristics of epilithic and endolothic algal turf exposed to different levels of bioerosion in French Polynesia coral reefs. Oceanol Acta 21:695-697

Le Campion-Alsumard T (1979) Les Cyanophycées endolithiques marines: systématique, ultrastructure, écologie et biodestruction. Oceanol Acta 2:143-156

Le Campion-Alsumard T, Golubic S, Hutchings PA (1995) Microbial endoliths in skeletons of live and dead corals: Porites lobata (Moorea, French Polynesia). Mar Ecol Prog Ser 117:149-157

Littell RC, Milliken GA, Stroup WW, Wolfinger RD (2006) $\mathrm{SAS}^{\circledR}$ for mixed models, 2nd edn. SAS Institute, Cary, NC

Mao Che L, Le Campion-Alsumard T, Boury-Esnault N, Payri C, Golubic S, Bezac C (1996) Biodegradation of shells of the black pearl oyster Pinctada margaritifera var. cumingii, by microborers and sponges of French Polynesia. Mar Biol 126:509-519

McClanahan TR (2002) The near future of coral reefs. Environ Conserv 29:460-483

- McClanahan TR, Cokos BA, Sala E (2002) Algal growth and species composition under experimental control of herbivory, phosphorus and coral abundance in Glovers Reef, Belize. Mar Pollut Bull 44:441-451

McClanahan TR, Sala E, Stickels P, Cokos BA, Baker A, Starger CJ, Jones S (2003) Interaction between nutrients and herbivory in controlling algal communities and coral condition on Glovers Reef, Belize. Mar Ecol Prog Ser 261: 135-147

McClanahan TR, Steneck RS, Pietri D, Cokos B, Jones S (2005) Interaction between inorganic nutrients and organic matter in controlling coral reef communities in Glovers Reef, Belize. Mar Pollut Bull 50:566-575

McClanahan TR, Carreiro-Silva M, DiLorenzo M (2007) Effect of nitrogen, phosphorus, and their interaction on coral reef algal succession in Glover's Reef, Belize. Mar Pollut Bull 54:1947-1957

Mellilo JM, Naiman RJ, Aber JD, Linkins AE (1984) Factors controlling mass loss and nitrogen dynamics of plant litter decaying in northern streams. Bull Mar Sci 35:341-356

Miller MW, Hay ME, Miller SL, Malone D, Sotka EE, Szmant AM (1999) Effects of nutrients versus herbivory on reef algae: a new method for manipulating nutrients on coral reefs. Limnol Oceanogr 44:1847-1861

Parsons TR, Maita Y, Lalli CM (1984) A manual of chemical and biological methods for seawater analysis. Pergamon Press, New York

> Perkins RD, Tsentas CI (1976) Microbial infestations of carbonate substrates planted on the St. Croix shelf, West Indies. Geol Soc Am Bull 87:1615-1628

Peyrot-Clausade M, Le Champion-Alsumard T, Hutchings $\mathrm{P}$, Le Campion J, Payri C, Fontaine MF (1995) Initial bioerosion and bioaccretion on experimental substrates in high island and atoll lagoons (French Polynesia). Oceanol Acta 18:531-541

Radtke G (1993) The distribution of microborings in molluscan shells from recent reef environments at Lee Stocking Island, Bahamas. Facies 29:81-92

Editorial responsibility: Charles Birkeland,

Honolulu, Hawaii, USA
Radtke G, Golubic S (2005) Microborings in mollusk shells, Bay of Safaga, Egypt: morphometry and ichnology. Facies 51:118-134

Radtke G, Le Campion-Alsumard T, Golubic S (1996) Microbial assemblages of the bioerosional 'notch' along tropical limestone coasts. Algol Stud 83:469-482

> Risk MJ, Sammarco PW, Edinger EN (1995) Bioerosion in Acropora across the continental shelf of the Great Barrier Reef. Coral Reefs 14:79-86

Rose CS, Risk MJ (1985) Increase in Cliona delitrix infestation of Montastrea cavernosa heads on an organically polluted portion of the Grand Cayman fringing reef. PSZN I: Mar Ecol 6:345-363

Sammarco PW, Risk MJ (1990) Large-scale patterns in internal bioerosion of Porites: cross continental shelf trends on the Great Barrier Reef. Mar Ecol Prog Ser 59:145-156

SAS Institute (2004) User's manual, Ver. 9.0. SAS Institute, Cary, NC

Schneider J, Torunski H (1983) Biokarst on limestone coasts, morphogenesis and sediment production. PSZNI: Mar Ecol 4:45-63

Sokal RR, Rohlf FJ (1995) Biometry, 3rd edn. WF Freeman, San Francisco, CA

Szmant AM (2002) Nutrient enrichment on coral reefs: Is it a major cause of coral reef decline? Estuaries 25:743-766

Thacker RW, Ginsburg DW, Paul VJ (2001) Effects of herbivore exclusion and nutrient enrichment on coral reef macroalgae and cyanobacteria. Coral Reefs 19:318-329

> Tomascik T (1991) Settlement patterns of Caribbean scleractinian corals on artificial substrata along an eutrophication gradient, Barbados, West Indies. Mar Ecol Prog Ser 77: 261-269

Tribollet A (2008a) The boring microflora in modern coral reef ecosystems: a review of its roles. In: Wissak M, Tapanila $\mathrm{L}$ (eds) Current developments in bioerosion. SpringerVerlag, Berlin, p 67-94

Tribollet A (2008b) Dissolution of dead corals by euendolithic microorganisms across the northern Great Barrier Reef (Australia). Microb Ecol 55:569-580

Tribollet A, Golubic S (2005) Cross-shelf differences in the pattern and pace of bioerosion of experimental carbonate substrates exposed for 3 years on the northern Great Barrier Reef, Australia. Coral Reefs 24:422-434

Tribollet A, Decherf G, Hutchings PA, Peyrot-Clausade M (2002) Large-scale spatial variability in bioerosion of experimental coral substrates on the Great Barrier Reef (Australia): importance of microborers. Coral Reefs 21: $424-432$

Tudhope AW, Risk MJ (1985) Rate of dissolution of carbonate sediments by microboring organisms, Davies Reef, Australia. J Sediment Petrol 55:440-447

> Vogel K, Gektidis M, Golubic S, Kiene WE, Radtke G (2000) Experimental studies on microbial bioerosion at Lee Stocking Island, Bahamas and One Tree Island, Great Barrier Reef, Australia: implications for paleoecological reconstructions. Lethaia 33:190-204

> Ward S, Harrison P (2000) Changes in gametogenesis and fecundity of acroporid corals that were exposed to elevated nitrogen and phosphorus during the ENCORE experiment. J Exp Mar Biol Ecol 246:179-221

- Ward-Paige CA, Risk MJ, Sherwood OA, Jaap WC (2005) Clionid sponge surveys on the Florida Reef Tract suggest land-based nutrient inputs. Mar Pollut Bull 51:570-579

> Wissak M, Gektidis M, Freiwald A, Lundalv T (2005) Bioerosion along a bathymetric gradient in a cold-temperate setting (Kosterfjord, SW Sweden): an experimental study. Facies 51:93-117 